\title{
REGIONÁLIS FOLYAMATOK AZ EU-CSATLAKOZÁS UTÁNI ÉVEKBEN LENGYELORSZÁGBAN
}

\author{
(Regional Development Processes after the EU-Accessions \\ in Poland)
}

\section{PUSZTAI JÓZSEF}

Kulcsszavak:

Lengyelország EU-csatlakozás gazdasági növekedés regionális divergencia

Lengyelország az EU-csatlakozás után tovább gyorsuló gazdasági konvergenciát mutat az EU magállamaihoz viszonyítva. Az országon belül azonban tovább nött a régiók közötti eltérés, azonban a divergencia sebessége csökkent. Ennek folyamatát, okait és mértékét mutatja be a tanulmány a gazdaság-matematika eszköztárát is felhasználva.

\section{Az EU-csatlakozás utáni regionális folyamatok}

Az ország regionális folyamataiban jelentős változást hozott az európai uniós csatlakozás, már csak a későbbiekben részletesen tárgyalt hatalmas forrásbevonás miatt is. Tézisünk szerint a lengyel régiók között a divergencia folytatódott, bár sebessége jelentős mértékben csökkent a csatlakozás előtti évekhez képest. Mindeközben az ország egésze erősen konvergált az unió fejlett államaihoz. Ez természetesen siker, még akkor is, ha az elemzésbe csak 2003-2006 (esetenként 2007) adatai szerepelnek a statisztikai elérhetőség miatt. 2003 felvételére (csatlakozás előtti utolsó év) kizárólag az idősor megfelelő hosszának előállítása céljából volt szükség, az eredményt nem módosítja, amint ezt az 1 . ábra mutatja.

\section{A csatlakozás utáni kihívások}

Az uniós források lehívása (amelyek a lengyel GDP 4\%-át érik el) a divergenciát mérsékelni tudta ebben a négy évben, de megállítani nem. Általános európai tapasztalatként itt is jellemző, hogy míg az egész ország konvergál az Európai Unió régi tagállamaihoz, beleértve a régiókat is, addig az egyes régiók egymáshoz képest divergálnak (Lobatch 2009). 
Pusztai József : Regionális folyamatok az EU-csatlakozás utáni években Lengyelországban.

Tér és Társadalom 24. évf. 2010/1. 175-184. p.

176 Kitekintó

TÉT XXIV. évf. 2010 a 1

Az országban háromféle elméleti szcenárió versengett az uniós források elosztásának mikéntjéért, úgymint:

- „egyenlö”, lakosság arányú pénzelosztás (equal): ez az ország konvergenciáját segíti, de nem támogatja a régiókat. Gazdaságilag nem igazán hatékony, politikailag közepesen nehéz megvalósítani.

- kiegyenlítő (equity): ezen esetben az elmaradottság foka szerint pozitívan diszkriminálnak. Ezen esetben a régiók közötti divergencia lelassulhat, sőt, akár meg is állhat, viszont a versenyképes területek fejlödése elmarad az optimálistól, mivel a pluszforrás nem náluk hasznosul, ezért rövid távon csökkenti az egész ország konvergenciáját (Lobatch 2009). Mi magunk egyáltalán nem vagyunk erről meggyőződve, mivel álláspontunk szerint a társadalmi kohézió szempontjából ez volna a leghasznosabb.

- Hatékonyság alapú (efficiency): ez a megoldás szimpla piaci logikán nyugszik, mégpedig a leggyorsabban fejlődő régió kapja a legtöbbet, mert ott termelödik az egy egységnyi befektetett EU-pénzre a legtöbb növekedési egység. Ezen logika tovább polarizálja a különbségeket, azonban vélhetően rövid távon (de csak rövid távon!) növeli az egész ország konvergencia sebességét. A politikai kivitelezhetőség kockázata nagy (Lobatch 2009).

\section{1. ÁBRA}

A 2003-2006 közötti átlagos növekedési ráták és az 1 före jutó GDP-re vonatkozó regresszioja

(Regression of the Annual Average Growth Rate and GDP/capita between 2003 and 2006)

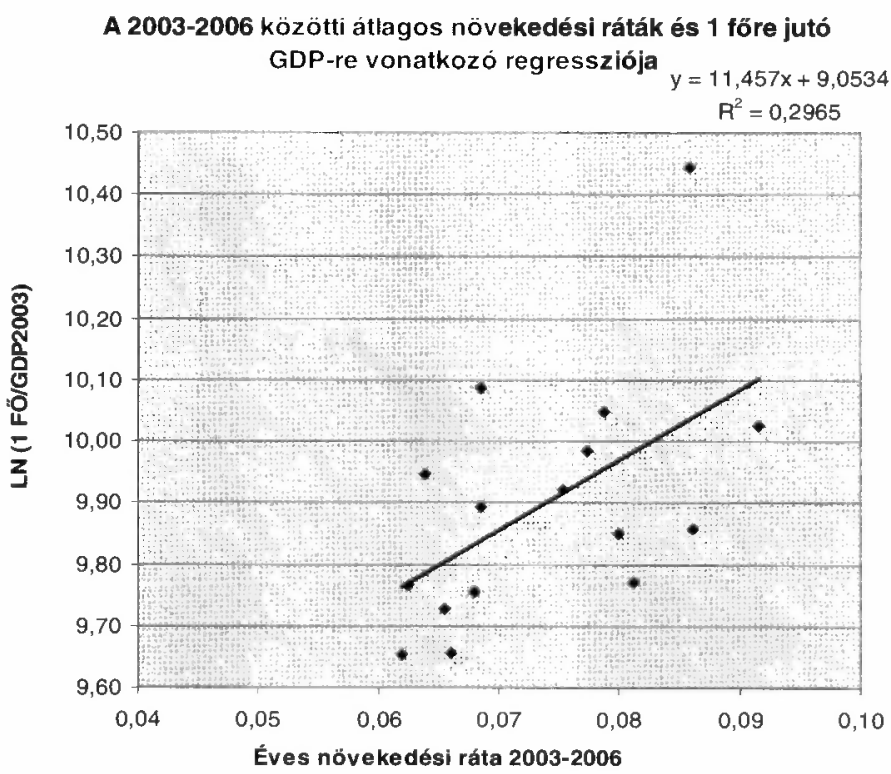

Forrás: Az OECD Regional Database (2009) alapján saját számítás. 
Pusztai József : Regionális folyamatok az EU-csatlakozás utáni években Lengyelországban. Tér és Társadalom 24. évf. 2010/1. 175-184. p.

Meglátásunk szerint az ország az egyenlő és a kiegyenlítő megoldásokhoz hasonló szisztémához nyúlt, mert csak kohézió mentén tartható fenn a hosszú távú harmonikus növekedés, amit a csökkenỏ sebességủ divergencia is visszaigazolt, míg Európa egyik leggyorsabban növekvő gazdaságaként a konvergencia sebességébỏl sem veszített lényegesen (OECD 2009). Még akkor is, ha Krugman (1991) (a világgazdasági válságot előrejelző Nobel-emlékdíjas) és más hazai (pl. Gorzelak [1999]) közgazdászok az efficiency megoldást preferálták, a döntést helyesnek tartjuk.

\section{EU-alapok Lengyelország számára}

Az EU-csatlakozás után a regionális rendszer valódi „stressz tesztje” jól sikeruilt, mivel modernizálta az államigazgatást, a régiók menedzsment tudását növelte és fejlesztette a partnerséget és a flexibilis kormányzást (Pálné Kovács 2009).

Az Uniós alapok rendelkezésre állása a csatlakozás és 2006 májusa, azaz az első 24 hónap után nettó 2,8 milliárd euró pozitív transzfert jelentett. 2006-ban a GDP 1,2\%-át, 2007-ben 1,5\%-át, 2008-ban 3,25\%-át tette ki a transzfer összege. Az első két év EU-transzfereinek szektoronkénti megoszlását mutatja a 2. ábra.

\section{2. ÁBRA}

A Lengyelországba érkezó EU-transzferek struktúrája \%-ban, (2004. május 1-jétöl 2006. április 30-ig) (Structure of the EU-Transfers into Poland in \%)

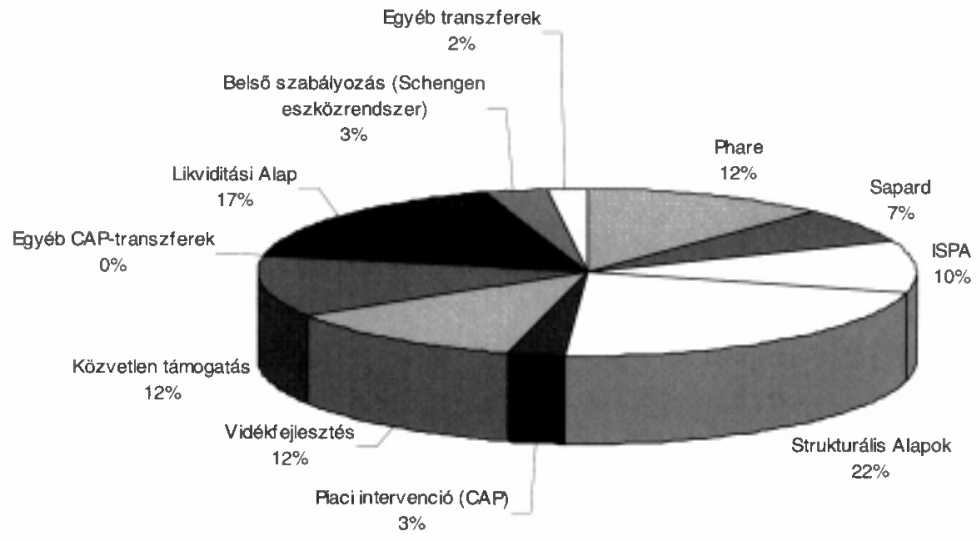

Forrás: Lengyel kormányzat (2006).

$\mathrm{Az}$ alapok elérhető összegeinek a lehívása az első három évben viszonylag lassú volt (50,7\%-ra született meg jóváhagyott szerződés), ennek elsőrendủ oka a rendkívül decentralizált rendszer, amely meghosszabbítja a folyamatokat, és több koordinációt igényel. (Természetesen ezzel együtt mélyen demokratikus, illetve optima- 
Pusztai József : Regionális folyamatok az EU-csatlakozás utáni években Lengyelországban.

Tér és Társadalom 24. évf. 2010/1. 175-184. p.

178 Kitekintö

TÉT XXIV. évf. 2010 — 1

lizálja az elosztást, mivel rendkívül sok szempontot érvényesít.) Második ok a még mindig nem teljesen kiforrott jogi háttér, amelyet folyamatosan kell adoptálniuk. Harmadik pedig a több mega projekt, amelyeknél természetes a hosszabb koordináció. Az EU-csatlakozás lakossági támogatása is folyamatosan nőtt a belépéskori 71\%-ról a mai $83 \%$-ra, mintegy igazolva az elmúlt évek gazdasági és politikai sikereit (Balcerowicz, 2007).

\section{Mennyire hatékony a regionális fejlesztési politika a csatlakozás óta?}

Az eltelt négy évben igazán csak az utolsó kettőben mérhetô szignifikáns javulás, de mindhárom (az EU által használt) makromodell elörejelző rendszer jelentős pozitív GDP növelö hatást jelez a következő évtizedre (1. táblázat). (Ezen modelleket természetesen komoly kritikával illethetjük, ezen módszertani elemzés azonban nem tárgya a dolgozatnak.)

\begin{tabular}{|c|c|c|c|}
\hline & & HELNMTIV & Quest II \\
\hline 2006 & 0,0 & 0,0 & 0,0 \\
\hline 2010 & 2,6 & 2,6 & 1,9 \\
\hline 2015 & 8,2 & 4,6 & 5,0 \\
\hline 2020 & 10,4 & 3,5 & 4,2 \\
\hline
\end{tabular}

Megjegyzés: Az EU-alapok hatása a lengyel gazdaságra a GDP-növekedés \%-ában (összehasonlítva a támogatások nélküli növekedéssel).

Forrás: Bradley-Untiedt (2007).

\section{Kohéziós politika}

Lengyelország az első programozási szakaszban (2004-06) 12,8 Mrd eurót kapott, mely összeg a negyedik legnagyobb volt az Unióban. A 2007-2013 közötti idöszakban az ország 67 Mrd eurót kap csak a kohéziós keretböl, ami az egész uniós kohéziós keret $20 \%$-a.

Mivel ekkor már Lengyelország kapja a legnagyobb összeget, ezért az EU egyfajta hatékonyság elemző laboratóriumként figyeli az országot, melynek a tapasztalatai döntően fogják befolyásolni az egész EU kohéziós politikáját (Freyberg 2008). A két szakasz kohéziós politikájának pénzelosztását mutatja operatív szinten a 2. táblázat és a 3. táblázat. 
Pusztai József : Regionális folyamatok az EU-csatlakozás utáni években Lengyelországban. Tér és Társadalom 24. évf. 2010/1. 175-184. p.

TÉT XXIV. évf. 2010 『 1 Kitekintö

\section{TÁBLÁZAT}

Az EU-források Operativ Programok közötti eloszlása, 2004-2007

(a teljes összeg százalékában)

(Distribution of EU-Transfers between the Operative Programs, 2004-2007)

\begin{tabular}{lc}
\hline \multicolumn{1}{c}{ Operatív Program } & A teljes összeg százaléka \\
\hline Kohéziós Alap & 41 \\
Közlekedés & 8 \\
Humán erőforrás & 9 \\
Versenyképesség & 8 \\
Regionális program & 22 \\
Mezőgazdaság & 9 \\
Halászat & 1 \\
Kiegyenlítési program & 1 \\
Interreg program & 1 \\
\hline
\end{tabular}

Forrás: „Raport o rozwoju... (2007).

\section{TÁBLÁZAT}

EU-források eloszlása az Operativ Programok között 2007 és 2013 között (a teljes összeg százalékában)*

(Distribution of EU-Transfers between the Operative Programs, 2007-2013)

\begin{tabular}{lc}
\hline \multicolumn{1}{c}{ Operatív Program } & A teljes összeg százaléka \\
\hline Infrastruktúra és Környezet & 41,50 \\
Emberi eröforrás & 14,40 \\
Innovatív gazdaság & 12,30 \\
Regionális programok (16) & 24,60 \\
Európai térségi fejlesztés & 1,10 \\
Kelet-Lengyelország fejlesztése & 3,40 \\
Technikai segítség & 0,80 \\
Végrehajtási tartalék & 1,90 \\
\hline
\end{tabular}

*A térségi fejlesztésre fordított alapok (Mezögazdasági és Halászati Programok 2004-2006) a Kohéziós Alapoktól elkülönítettek.

Forrás: Ministry of Regional Development (2007); OECD (2009).

Mindkét periódusban a legnagyobb összegek a környezetvédelmi és a közlekedési projektekre költődnek, mivel a lengyel infrastruktúra rendkívül alulfejlett. Másodszor a nagyobb projekteket az első betanulási szakaszban könnyebb biztosan kezelni, mint a kisebbeket tömegesen. Harmadszor pedig politikailag is látványosabbak a nagy infrastrukturális beruházások (Freyberg 2008). A regionális operatív programok költséghely szerinti elosztását a 4. táblázat mutatja. 
Pusztai József : Regionális folyamatok az EU-csatlakozás utáni években Lengyelországban.

Tér és Társadalom 24. évf. 2010/1. 175-184. p.

180 Kitekintö

TÉT XXIV. évf. 2010 घ 1

\section{TÁBLÁZAT}

A Regionális Operativ Programok kiadásainak eloszlása 2007-2013 között

(a teljes összeg százalékában)

(Distribution of Expenditure of the Regional Operative Programs, 2007-2013)

\begin{tabular}{lcccc}
\hline \multicolumn{1}{c}{ Cél } & $\begin{array}{c}\text { A leggazda- } \\
\text { gabb régió* }\end{array}$ & $\begin{array}{c}\text { A legszegé- } \\
\text { nyebb ré- } \\
\text { gió** }\end{array}$ & $\begin{array}{c}\text { Lengyel- } \\
\text { ország }\end{array}$ & EU \\
\hline K+F, vállalkozás & 15,92 & 14,02 & 17,07 & 16,89 \\
Információs társadalom & 11,63 & 4,54 & 5,77 & 3,75 \\
Közlekedés & 36,15 & 43,27 & 35,53 & 24,50 \\
Energia & 1,77 & 3,28 & 3,46 & 2,50 \\
Környezetvédelem & 14,73 & 7,09 & 13,44 & 15,00 \\
Kultúra és turizmus & 3,12 & 4,86 & 3,27 & 3,10 \\
Humánerőforrás- & 12,25 & 13,29 & 13,00 & 23,00 \\
fejlesztés & 2,88 & 6,28 & 4,24 & 5,50 \\
Szociális infrastruktúra & 0,68 & 1,74 & 2,58 & 2,50 \\
Területfejlesztés & 0,87 & 1,65 & 1,66 & 1,70 \\
Intézményi és admi- & & & & \\
nisztrációs potenciál & &
\end{tabular}

*Mazowieckie (81,2\% az egy före eső GDP 2005-ben, PPS-ben, EU27=100)

** Lubelskie (35,0\% az egy före esö GDP 2005-ben, PPS-ben, EU27=100)

Forrás: Ministry of Regional Development (2008).

A 4. táblázatból is látszik, hogy a fenti két fỏ befektetési területen kívül a további három legfontosabb terület Lengyelország számára a $\mathrm{K}+\mathrm{F}$ és a vállalkozásfejlesztés, az információs társadalom és a humán erőforrás fejlesztése.

Az elmúlt négy év lényegi következtetéseit a régiók, az ország és az Unió számára a következökben összegezhetjük (Freyberg 2008):

1) Az EU kohéziós politikájának pozitív hatása kisebb az elvártnál, a divergencia nem állt le, csak mérséklödött;

2) Pontosabb hatékonyság mérési metódusok szükségeltetnek;

3) Jobban fókuszáljanak a régiók az oktatásra és az infrastruktúra-fejlesztésre, saját stratégiájukat kialakítva ezeken a területeken;

4) Több technikai segítség kell az új tagállamoknak az EU-tól az adminisztráció és a szabályozás fejlesztésének területén;

5) Lengyelország megfelelö teszt ország az EU bizottság számára a jövő uniós regionális politikájának alakításához;

6) Lengyelország számára a szabályozás minőségének folyamatos javítása elengedhetetlen;

7) A lengyel régiók alapvetően jól felkészültek és motiváltak az alapok pénzeinek sikeres felhasználására. 
Pusztai József : Regionális folyamatok az EU-csatlakozás utáni években Lengyelországban. Tér és Társadalom 24. évf. 2010/1. 175-184. p.

TÉT XXIV. évf. 2010 曰 1 Kitekintor 181

\section{Az OECD elemzése a csatlakozás utáni regionális politika eredményeiról}

Az objektivitás szempontja miatt fontosnak tartjuk, hogy röviden kitérjünk egy, az EU-tól közvetlenül nem függő tekintélyes szervezet elemzéseire is. Elemzésük (OECD 2009) összegzéseként kiemelik a növekvő regionális különbségeket, amelyek különösen három dimenzió mentén kritikusak és kezelendők: elsőként az ország keleti és nyugati részének távolodását, másodikként Varsó és az ország öszszes többi területének távolodását, végül pedig a kỏzponti városok és a peremterületek közötti intraregionális különbségek növekedését emelték ki. Megoldásként alapvetően szintén a humán tőke, az innovációs képesség és az infrastruktúra további fejlesztését javasolják, kiemelve még az FDI és a vidékfejlesztés nagyon fontos modernizációs szerepét.

\section{Regionális fejlesztés kihívásai}

A nagyvárosok és a rurális területek közötti növekedésbeli eltérés megmaradt a csatlakozás után is, ennek csökkentése a legfóbb kihívás. Itt fỏ magyarázó faktorként a magasabb foglalkoztatás és a termelékenység jelenik meg (3. és 4. ábra).

A második kihívás a Varsó és a többi centrum közötti divergencia megállítása, melyet legfőképp a szolgáltató szektor varsói dominanciája magyaráz (5. ábra).

Ami Varsó esetében természetesen tovább növeli a tỏkevonzó képességet is (6. ábra).

\section{3. ÁBRA}

Az egy före esó reál GDP a régiók típusa szerint Lengyelországban, 2005 (lengyel zloty)

(Real GDP per Capita by the Type of Regions in Poland, 2005)

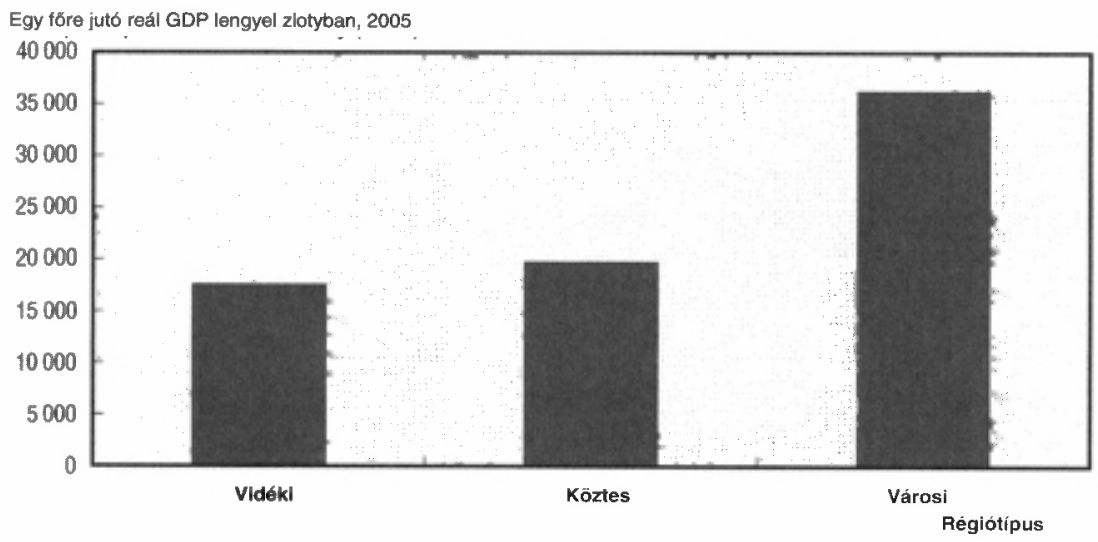

Forrás: OECD $(2009,55)$. 
Pusztai József : Regionális folyamatok az EU-csatlakozás utáni években Lengyelországban.

Tér és Társadalom 24. évf. 2010/1. 175-184. p.

\section{4. ÁBRA}

A nemzeti átlagnövekedéstöl való eltérés magyarázó tényezöi

(Explanatory Factors for the Deviation from National Average Growth)

Termelékenységi GDP-differencia

20

Aktivitási rátának köszönhető GDP-differencia

Foglalkoztatásnak köszönhető

GDP-differencia

Százalékos különbség a GDP-ben (2005)

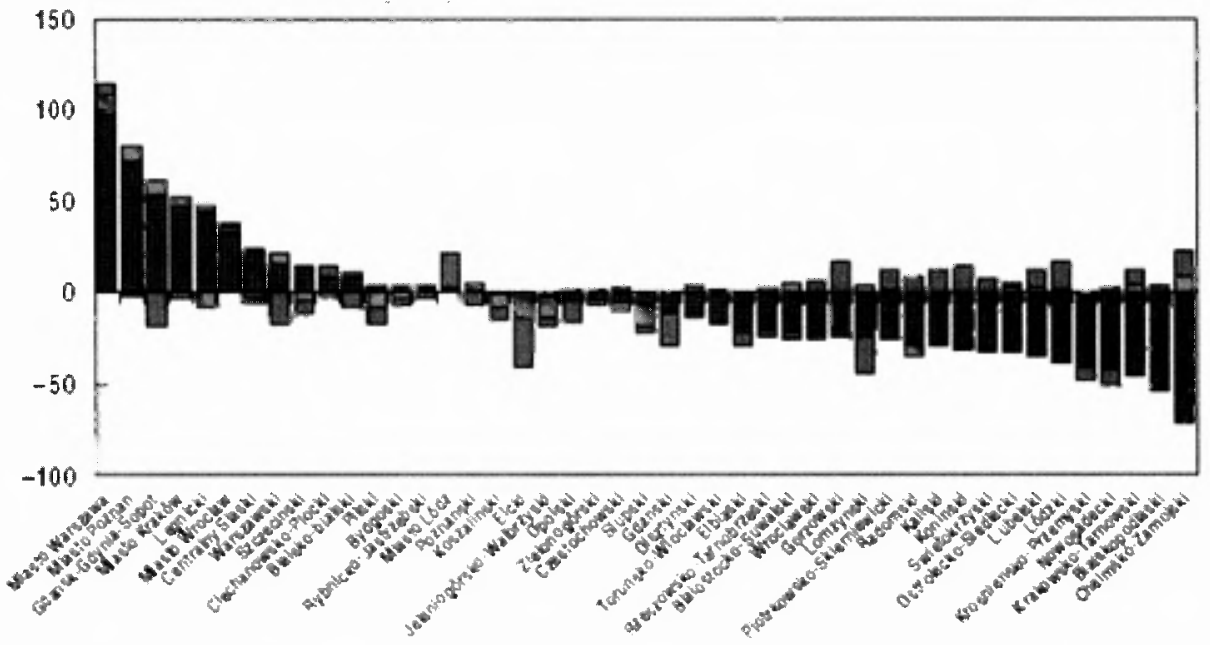

Megjegyzés: a „Miasto” várost jelent.

Forrás: OECD $(2009,55)$.

\section{5. ÁBRA}

Egy före jutó GDP a lengyel városokban, 2005-ben

(GDP per Capita in Polish Cities in 2005)

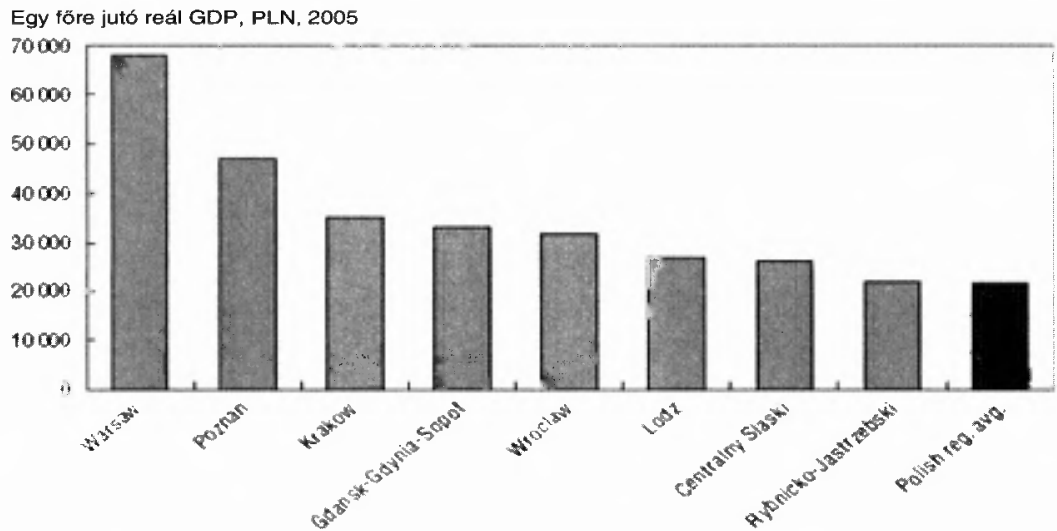

Megjegyzés: Az ábra csak a nyolc túlnyomórészt városi területet mutatja Lengyelországban az OECD Regionális Database definícióinak megfelelöen.

Forrás: OECD $(2009,57)$. 
Pusztai József : Regionális folyamatok az EU-csatlakozás utáni években Lengyelországban.

Tér és Társadalom 24. évf. 2010/1. 175-184. p.

TÉT XXIV. évf. 2010 a 1

Kitekintö

183

\section{6. ÁBRA}

Növekvö különbségek a müködö tökevonzó képességben

(FDI-növekedés és a kezdeti szintek)

(Increasing Disparities in Attracting FDI [FDI-Growth and Starting Levels])

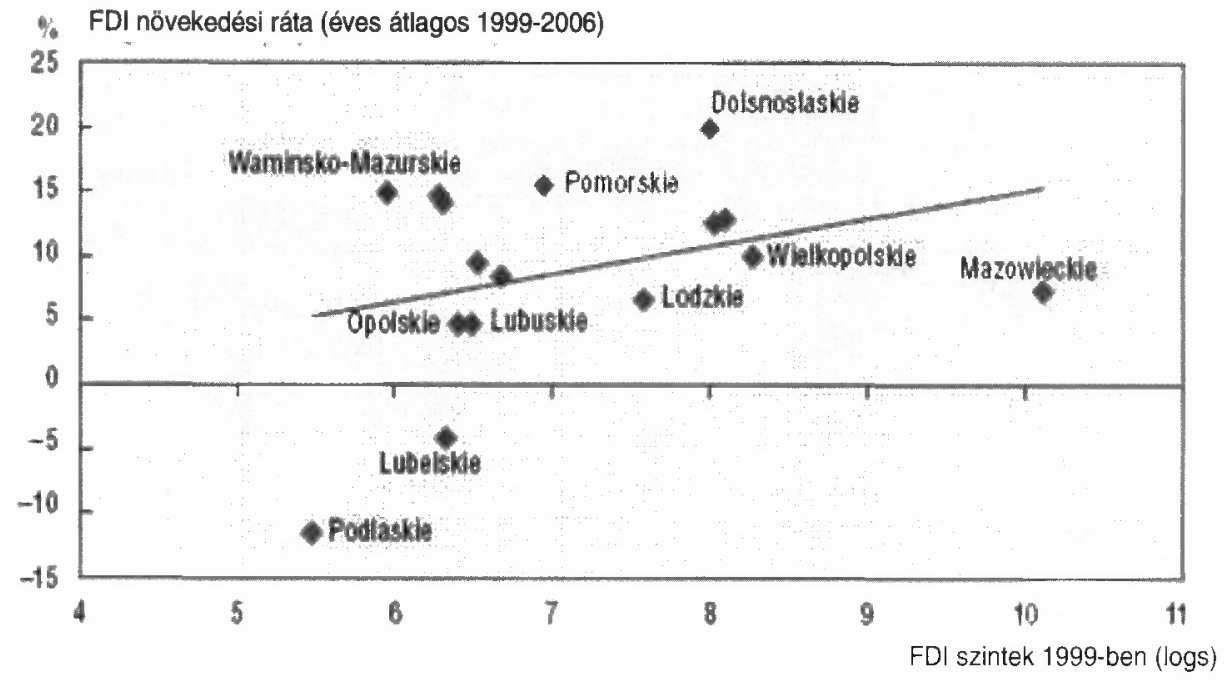

Az adatok TL3-szinten nem állnak rendelkezésre.

Forrás: $\mathrm{OECD}(2009,58)$.

Ezen a területen a megoldás a humántőke további fejlesztésén túl a nagyvárosok specializálódása néhány kiemelt tudásalapú területre, amelyeken keresztül direkt módon is kapcsolódhatnak a világgazdaság és az EU gazdasági keringéséhez, ezáltal az ország gazdasági növekedésének még inkább a motorjaivá válva.

A harmadik kihívás pedig a rurális területek szerepének a megtalálása, fejlesztése, ami sajnos még mindig csak zömében alacsony hatékonyságú mezőgazdasági termelést jelent. Ebben jelentős változást a négy uniós év nem hozott. Tapasztalatként elmondható, hogy jelentősen növelni kell, és minőségében, célzottságában is javítani kell a terület pénzügyi transzfereit, növelni a szociális védelmet, különös tekintettel a foglalkoztatás védelmére és a KAP lehetőségeinek hatékony felhasználására. (Mindezen megállapítások egzakt módon matematizálhatók is, ez azonban nem a cikk része, de lásd $O E C D$ 2009)

Összegzésképp elmondható, hogy minden „korai betegsége” ellenére az EUcsatlakozás kihasználása mind az ország, mind a régiók, mind pedig a lakosság érzete alapján sikeres volt. 


\section{Irodalom}

Balcerowicz, E. (2007) The Impact of Poland's EU Accession on ist Economy. Center for Socail and Economic Research, Warsaw.

Bradley, J.-Untiedt, G. (2007) „Do Economic Models Tell us Anything Useful about Coheson Policy Impact." - GEFRA Working Papers. 3.

Freyberg, E. (2008) How effective are regional development policies? Warsaw School of Economics, Warsaw.

Gorzelak, G. (1999). Reghional Policies and regional Capacity-Building in Poland. - Brusis, M. (ed.) Central and Eastern Europe on the Way to the European Union: Regional Policy Making in Bulgaria, the Czech Republic, Estonia, Hungary, Poland and Slovakia. Centrum fuer Angewandte Politikforschung. /www.cap.uni-muenchen.de/download/2000/RPPoland.PDF

Krugman, P. (1991) Geograph and Trade. MIT Press, Cambridge.

Lobatch, A.I. (2009) EU membership and growing regional disparities: Poland's strategy options to optimise structural transfers from the Union. Belarus State Economic University, Belarus. http://unpanl.un.org/intradoc/groups/public/documents/NISPAcee/UNPAN018524.pdf; (Letöltve: 2009. 08. 29.)

Myrdal G. (1957) „Economic theory and underdeveloped regions." Duckwort, London.

OECD (2009) Annex 1.A1. Econometric Model to Measure Regional Economic Growth. - OECD Territorial Reviews: Poland. OECD Publishing, Paris.

Pálné Kovács, I. (2009) Europeanisation of Territorial Governance in Three Eastern/Central European Countries. - Halduskultuur. 10. 40-57. o.

„Raport o rozwoju i polityce regionalnej." (2007) Ministerstwo Rozwoju Regionalnego, Warszawa. 